\title{
Chapter 3: Socioeconomic Inequality and Student Outcomes in English Schools
}

Jake Anders \& Morag Henderson (UCL Institute of Education)

Corresponding Author: jake.anders@ucl.ac.uk

\section{Accepted pre-print version}

\begin{abstract}
This chapter explores socioeconomic inequality in educational outcomes in England. We begin by describing the key features of the English education system and highlight the characteristics of the student population. We explore the educational outcomes of socioeconomically disadvantaged young people through comparison of a number of different outcomes during educational careers. We analyze policies introduced or mooted in recent years to consider the extent to which they are likely to address these challenges successfully. These include the introduction of "academy" schools, reforms to the school curriculum, changes to education funding, the potential (re-)growth of academically selective schooling, increased investment in early years education, and an increased focused on gathering and disseminating robust evidence on 'what works' in educational attainment. Many of these changes seem unlikely to hold many lessons for other countries wishing to reduce attainment gaps. However, there are notable exceptions, particularly regarding early years' education and improving the evidence base on what practical changes schools can make to promote attainment among those from disadvantaged backgrounds.
\end{abstract}




\section{Introduction}

This chapter explores socioeconomic inequality in educational outcomes in England. We focus on England rather than the whole of the UK because education policy in Wales, Scotland, and Northern Ireland is devolved to these countries' parliaments or assemblies. As such, the UK Government's Department for Education (DfE) only sets policy for England. We begin by describing the key features of the English education system and highlight the characteristics of the student population; we explore the educational outcomes of socioeconomically disadvantaged young people and analyze the policies introduced or mooted in recent years to consider the extent to which they are likely to address these challenges successfully.

Children in England must participate in full-time education between the school term after their 5th birthday until they turn $18 .{ }^{1}$ State-funded schooling in England is free at the point of use at both primary (ages 5-11) and secondary (ages 12-18) phases. State- and privately funded schools exist at both of these phases.

Private schools are funded by fees, bequests, and commercial activities. As such, they operate relatively independently; for example, they can set their own admission policies, which may include an admissions test, and school governance is a matter for the school itself (within some fairly light-touch regulations). Nevertheless, they are subject to an inspection regime, albeit one that is different to that which oversees state-funded schools. Approximately $7 \%$ of pupils in English education at any given time are in a privately funded school, while around $11 \%$ attend a privately funded school at some point in their educational career.

\footnotetext{
${ }^{1}$ In 2015 the DfE made an exception for deferring primary schooling in cases where the child was deemed not ready to start school, for example summer-born children (born between 1st April - 31st August).
} 
State-funded schools can be divided into two categories, generally known as "maintained" schools, which are funded and controlled by local authorities, and "academies" whose funding comes direct from the DfE and, thus, are outside local authority control but may instead be controlled by a sponsor or part of a multi-academy trust. The policy of academy schools as a turnaround model for schools deemed to be persistently failing had been introduced by the New Labour government in the mid-2000s with enforced academization being a package of measures including replacement of senior leadership and replacement of local authority oversight with external input from a sponsor. However, it was greatly extended post-2010 both for schools falling below floor standards (who would be sponsored by an external body,) or outstanding schools keen for more autonomy and financial control: academies no longer had a portion of their funding diverted to their local authority but, in return, had to provide the back office, such as payroll, previously provided centrally. This position of "academization" as a way of increasing school autonomy so that they can respond to local demands was key to the rhetoric of the coalition government's academies program. Academies were also part of a shift to a "self-improving school-led system" (Greany \& Higham, 2018) with academies (particularly those underperforming) encouraged to join multi-academy trusts which replaced many of the centralized functions of local authorities.

Formally, parents can exert a great deal of choice over the school to which they send their child. However, popular schools are often highly oversubscribed, resulting in schools picking pupils rather than vice versa. This school selection of pupils is largely based on geography (where the child lives) through a system of catchment areas, rather than on a child's attributes. Demand for high-performing state schools is such that some parents may move to different neighborhoods to improve their child's chances of accessing a good state-funded school, resulting in what is sometimes referred to as selection by house prices. We describe school 
selection as being largely based on geography because there are some exceptions to this. No primary schools are allowed to select based on academic ability but some secondary schools are (see below), while some schools may select children based on other characteristics; for example, belonging to a particular faith.

English schools monitor the attainment of children throughout compulsory education by means of national examinations at age 7 (Key Stage 1), 11 (Key Stage 2) in primary school, and 16 (Key Stage 4/General Certificate of Secondary Education/GCSE) in secondary school. At age 18 students take A-Level examinations (Key Stage 5) or equivalent vocational qualifications, which are generally seen as a prerequisite for participation in higher education (although other routes are possible).

The remainder of the chapter proceeds as follows. We first describe the key characteristics of the student population in England; we then focus on differences in educational achievement by socioeconomic characteristics in order to present a contextualized picture of the academic performance of low SES pupils in England. We then turn to policy, reviewing work that has sought to evaluate the educational policies adopted or announced by the government which were designed to address (or are otherwise likely to have significant implications for) socioeconomic disadvantage in educational attainment. Lastly, we conclude by summarizing the current picture and future prospects.

\section{Key Characteristics of the Student Population}

According to figures from the UK's DfE in $2017,91 \%$ of the 8.7 million school children in England attend state-funded schools (more specifically, 54\% attend state-funded primary schools and 37\% state-funded secondary schools), $7 \%$ attend privately-funded schools, and 
$1 \%$ attend special schools (DfE, 2017d). This section of the chapter will explore the key characteristics of the student population in England, with a particular focus on disadvantage.

\section{Gender}

According to the school census from 2017 (DfE, 2017d), the population in state-funded primary schools is $51 \%$ boys and $49 \%$ girls, whilst in state-funded secondary schools the gender split is 50-50. In special schools and pupil referral units, we see a starker gender split, with the full-time student population comprising $72 \%$ boys and $28 \%$ girls. Lastly, in private schools $51 \%$ of pupils are boys and $49 \%$ are girls.

\section{Household Income}

Table 1 shows the proportion of children, by region, in absolute and relative poverty averaged across 2013-2016 (Department for Work and Pensions [DWP], 2017a, 2017b). Relative low income is measured by identifying those children who live in households with income below $60 \%$ of the median in that year, whilst absolute low income is measured by identifying households with inflation-adjusted income below $60 \%$ of the median income compared to 2010/11. The proportion of children in relative poverty before housing costs (BHC) was highest in West Midlands (23\%) and lowest in the South East (13\%). In London the proportion of children living in poverty $\mathrm{BHC}$ was $17 \%$, but we see a much higher proportion of living in poverty after housing costs (AHC, 27\%) owing to the high costs of housing relative to other parts of the UK (McGuiness, 2018). In figures released by the DfE (2017d) about all school types, $14 \%$ of pupils claimed free school meals ${ }^{2}$, often used as a proxy for

\footnotetext{
${ }^{2}$ Children are eligible for free school meals if their parents are in receipt of income support, jobseekers allowance, child tax credit, or universal credit or if their annual gross income is no more than $£ 16,190$ and they are not entitled to Working Tax Credits.
} 
family income. This is the lowest proportion of all school students claiming free school meals since 2001.

$<$ TABLE 1 HERE $>$

\section{Minority Ethnic Origins}

According to the School Census (DfE, 2017d), the proportion of pupils from minority ethnic origins, that is, the pupils of compulsory school age and above who have been classified ${ }^{3}$ to an ethnic group or origin other than White British, has been rising steadily since 2006. As of $2017,32 \%$ of pupils in primary schools are of minority ethnic origins and in secondary schools the proportion of minority ethnic origins is $29 \%$. Asians make up the highest proportion of ethnic minority students in primary and secondary state schools $(10.7 \%$ for both) with White non-British making up the second highest proportion of ethnic minorities in primary and secondary state schools $(7.5 \%$ and $5.7 \%$, respectively).

\section{English as an Additional Language}

The proportion of pupils whose family use a language other than English at home has increased since 2006. This is not a measure of English proficiency (although it may be a proxy for this) nor a measure of recent immigration; instead, it should be seen as a measure of diversity. Twenty-one percent of pupils in primary schools are exposed to a language other than English at home, while in secondary schools the proportion is 16\% (DfE, 2017d).

\section{Regional Differences}

\footnotetext{
${ }^{3}$ Ethnicity is collected for all pupils and records the ethnicity as stated by the parent/guardian or pupil.
} 
In 2017 in England there were 8,669,080 children in schools. In terms of the number of pupils by school type by region in England there are some interesting statistics of note (DfE, 2017d). There are a greater number of school children of all ages in London (17\%) and the South East $(16 \%)$ than elsewhere. Whilst the North East has the fewest school children of all ages $(5 \%)$ followed by the East Midlands (8\%). The breakdown of school population by schools are very similar by region, with the exception of private schools where the highest proportion of children attend private schools in South East (11\%) and London (10\%) and the least in the North East (3\%), North West (4\%), Yorkshire and the Humber (4\%), and East Midlands $(4 \%)$. There is also some evidence of variation in the number of children in state-funded nurseries with London, North East, North West, West Midlands and East of England each accounting for $1 \%$, and the South West accounting for $0.31 \%$.

\section{Family Structure}

According to data from the UK's Office for National Statistics (2017), the most common type of family in the $\mathrm{UK}^{4}$ with dependent children are opposite-sex married couples, comprising $62 \%$ of all families with children $(\mathrm{N}=7,983) ; 0.18 \%$ accounting for Other family types. ${ }^{5}$ Lone parent families comprise $22 \%$ of all families with dependent children, $0.05 \%$ are same-sex cohabiting couples, and 16\% opposite-sex cohabiting couples. The number of same-sex couple families in the UK has been increasing steadily since 1996; this is likely associated with larger proportions of the population identifying as lesbian, gay, or bisexual.

\section{Parental Education}

\footnotetext{
${ }^{4}$ Data of family structure is based on the UK as a whole rather than England specifically.

${ }^{5}$ Civil partnerships were introduced in the UK in 2005.
} 
The PISA data from 2015 report the composition of parental education in England ${ }^{6}$ using the International Standard Classification of Education (ISCED) scale $(\mathrm{N}=12,978)$ based on students' report of their parents' qualifications. The conversion between ISCED and English qualifications is not straight forward, so our example qualifications are only illustrative. The results suggest that $43 \%$ of parents have achieved ISCED5A (equivalent to at least a first degree), that a fifth (20\%) of parents have an ISCED5B qualification (higher education below degree level) and that slightly fewer than this (18\%) have achieved ISCED 3A (A levels, taken two years after the end of compulsory education) as their highest qualification. A further $20 \%$ report their parents having qualifications equivalent to ISCED 3B (GCSEs, the UK's end of compulsory education examinations), while $3.3 \%$ of students report that their parents only having achieved ISCED1 or 2 (less than GCSEs) or have no qualifications.

\section{Educational Outcomes of Low SES Children}

In this section we consider how the educational outcomes of low SES children compared to their more advantaged peers. We explore this through a number of different outcomes through their educational careers, including reporting the size of the difference in PISA scores in reading, math, and science by parental education and position in the distribution of PISA's SES index, the official measures of relative performance of disadvantaged pupils at ages 11 and 16 , and post- 16 and post-18 educational destinations. We also explore a number of factors that may be associated with the emergence of these gaps in an English context.

PISA

\footnotetext{
${ }^{6}$ GCSEs are in category ISCED 3B \& C, however GCSEs, the qualification taken at age 16 in England, do not easily fit into ISCED.
} 
To explore relative performance in PISA scores by family background we plot average test scores in reading ${ }^{7}$ by parental education (using the measure described above) in Figure 1. For these purposes, we dichotomize parental education in two different ways. First, ISCED0-2 (which averages $4 \%$ of the sample over the years considered) versus ISCED3B-6 (averaging $96 \%$ of the sample) for comparability with other chapters in this volume; second, ISCED0-3B (which averages $25 \%$ of the sample over the years considered) versus ISCED 3A-6 (averaging $75 \%$ of the sample) for approximate comparability with national measures of disadvantage. We emphasize that the small size for the ISCED0-2 group in the English context means these results are likely to be particularly volatile.

\section{$<$ FIGURE 1 HERE $>$}

Whichever comparison we draw, there are substantial differences between children of parents with low parental education and the rest of the population in these outcomes. For the reasons given above, we focus on our national comparison definition (ISCED0-3B vs. ISCED 3A-6) where the gap between these two groups are approximately 25 PISA points (the same is true in math and science, which are not shown). There is little sign of significant or sustained narrowing over the time period we consider (PISA from 2006 to 2015).

\section{Official Measure of Educational Inequality}

For the purposes of English educational statistics, the government defined disadvantaged pupils as those who were registered as eligible for free school meals in the last six years; children who are 'looked after' by a local authority; and children who left care in England and Wales through adoption or via a Special Guardianship or a Child Arrangements Order (DfE,

\footnotetext{
${ }^{7}$ There are similar results if we use math or science scores, instead of reading.
} 
2018a). In $2017,32 \%$ of pupils taking national tests at age 11 were classed as disadvantaged (DfE, 2017b), while $27 \%$ of pupils taking national tests at age 16 were classed as disadvantaged (DfE, 2018b).

The government's official measure relative to disadvantaged pupils' performance is known as the attainment gap index (DfE, 2014). It reports the difference in the average rank position on the relevant national test of pupils not classified as disadvantaged minus the average rank position of pupils classified as disadvantaged. Rank position is used to allow comparison over time despite changes in the assessments during this period.

We adapt the official index slightly in order to improve interpretability. If we imagine that there are 100 children ranked by their test scores, our graphs report the difference in the average ranking (out of 100) in these pupils' test scores by whether they are deemed to be disadvantaged or not. We can also think of them as differences in mean percentile ranks between the two groups. Figure 2 reports this difference at age 16; the statistic is also produced at age 11, however it tells a similar story to that at age 11.

$<$ FIGURE 2 HERE $>$

Based on this official government definition of the attainment gap, there has been a narrowing of two percentile-rank places at age 16, from a difference of just over 20 (in 2011) to just below 18 (in 2017). The gap in average rankings is slightly narrower at age 11, but also narrows by two percentile ranks over the same period. 
In terms of post-16 educational transitions in England, in 2015/16 the plurality of pupils continued into a school "sixth form" (39\%), with a similar proportion going to a further education destination (38\%). Thirteen percent of pupils went to a sixth form college, $6 \%$ went into an apprenticeship, and 3\% went to an employment/training destination (DfE, 2017a). Beyond this, almost 50\% of pupils now go to Higher Education post-18 (DfE, 2017c). We go on to consider a number of other important educational outcomes and how they differ by family background. Moulton, Sullivan, Henderson, and Anders (2018) find that children of parents with degrees are over-represented in full-time education post-16 among this cohort making educational transition decisions in 2006 (Table 2). Furthermore, they are more heavily over-represented among the increasingly more academic tracks of taking A-levels and taking two or more so-called "facilitating" subjects (identified by the Russell Group of highly competitive universities as particularly important for further studies at these institutions).

\section{$<$ TABLE 2 HERE $>$}

\section{University Attendance Differences}

A key educational outcome in an English context is attendance at university. According to analysis by Anders (2012) there is a 43-percentage point gap in university attendance between the least and the most advantaged fifths of the population. Similar differentials in university entry have been documented by others using different data (Boliver, 2013; Chowdry, Crawford, Dearden, Goodman, \& Vignoles, 2013). Furthermore, Wakeling and Laurison (2017) highlight a large socioeconomic differential in entry to postgraduate courses, with those from less privileged backgrounds "only about 28 per cent as likely to obtain a postgraduate degree when compared with their peers from privileged origins" (Wakeling \& Laurison, 2017, p. 533). This gap is a relatively recent phenomenon occurring contemporaneously with the widening of access to undergraduate higher education. 


\section{When and Why Do These Differences Emerge?}

Most evidence suggests that socioeconomic differences in educational attainment emerge early in life (Anders \& Jerrim, 2017), although this is particularly difficult to quantify in children's early years. The evidence on how these gaps develop during schooling is difficult to interpret, with some finding little evidence that schools can be "prime movers" in reducing achievement gaps (Strand, 2016) and others finding that "there is less divergence in performance ... [among] pupils who attend the same schools" (Crawford, Macmillan, \& Vignoles, 2017, p. 88), suggesting schools can play a significant role in reducing divergence (at least among early high-achievers, who were the focus of this work).

There is a similar message from work by Anders (2017), considering the gap in university attendance in particular. This work tracks pupils' changes in expectations of university attendance through their adolescent years in order to understand differences by family background. It is notable that children from less advantaged backgrounds are considerably more likely to stop expecting to apply to university than those from more advantaged backgrounds during this period, suggesting that there is some widening of educational inequality through this period. This gap is not explained by differences in these individuals' academic attainment.

$<$ FIGURE 3 HERE $>$ 
Having an advantaged social background (captured via a range of measures) is consistently linked to taking a more demanding and prestigious curriculum. As shown in Figure 3, a lower proportion of young people who take applied subjects have highly educated parents and a higher proportion of young people who take more academically demanding subjects, such as STEM subjects, have highly educated parents. Henderson, Sullivan, Anders, and Moulton (2017) find that these socio-economic differences in subjects studied (in particular applied, STEM and EBacc-eligible ${ }^{8}$ subjects) are only partly explained by differences in prior attainment, while Anders, Henderson, Moulton, and Sullivan (2018b) highlight the important role that schools, and school composition, seem to play in shaping the subject choices that young people are able to make. Furthermore, Moulton et al. (2018) and Anders et al. (2018a) highlight how these differences are associated with subsequent educational transitions.

\section{Limitations of Data Sources}

It is important to acknowledge the limitations for assessing the differences in educational outcomes of low SES pupils of the datasets used as part of this chapter. Several authors having highlighted the limitations of using the administrative National Pupil Database (e.g., Ilie, Sutherland, \& Vignoles, 2017) and there are related limitations in using data from PISA, particularly in that information about SES is collected only from pupils and not from their parents (Jerrim \& Micklewright, 2014). As a result, we also draw on studies using data from some of England's cohort studies, in particular "Next Steps" (formerly known as the Longitudinal Study of Young People in England, LSYPE). These data include much richer measures of family SES, including direct parental reports, but the longitudinal data present possible limitations due to the reduction in representativeness of the sample (we make use of

\footnotetext{
${ }^{8}$ The Ebacc subjects were identified by the government as important for future academic study. The 'Ebacc' is a school performance measure introduced in 2010, comprising of five core subjects where students achieve a C grade or above in either: English, Mathematics, History or Geography, two sciences and a Modern or Ancient Language.
} 
the appropriate survey and design weights to try to account for this). Taken together, these data sources paint a consistent picture of educational inequality and therefore we can have increased confidence in the general narrative that emerges.

\section{Educational Policies Designed to Address Socioeconomic Disadvantage}

In this section we discuss policies aimed at addressing the socioeconomic attainment gap and evidence of their success or otherwise.

\section{Free Early Education}

England has increasingly invested in early education programs since the late 1990s. The "Sure Start" scheme was introduced in 1998 as an early intervention for children under age 4 to be delivered through local providers. These were designed to support families and parents; provide quality learning, play, and child care; and offer support regarding child health and special needs. Several policy changes since then have resulted in an entitlement to free early education effectively being universal across England since 2005 for 3- and 4-year olds. Since 2017 the government has offered 15 hours of early education for 38 weeks per year to all 3and 4-year olds and the most disadvantaged 2-year olds. As a result of these policies the number of 3 to 5-year-olds accessing places grew: more specifically, between 2008 and 2010 the number of children taking up places increased by around 5\% while between 2010 and 2015 it grew by 11\% (DfE, 2010, 2015). However, the push to increase the number of disadvantaged children attending early years had limited success; evidence from the DfE show that $58 \%$ of eligible children took up their places by January 2015 . Moreover, Stewart and Obolenskaya (2016) found that there was little evidence of the SES gap narrowing as a result of the increase in provision of early education from 1999 and 2004, but there was some 
evidence that the gap narrowed from 2007 to 2014. They speculate that this reflects the improvements in the quality of provision, including better qualified staff, and the introduction of an early-years foundation stage curriculum.

\section{Curriculum Reform}

The national curriculum, ${ }^{9}$ which includes math, science, English, physical education, computing, and religious education at all key stages and sex and relationship education at secondary school, must be taught to pupils aged 5-16 in local authority-maintained statefunded schools in England. This includes the majority of primary schools but no longer the majority of secondary schools because of the rise of academies (including free schools, discussed further below) which do not have to follow the national curriculum (although many do and they are required by their funding agreements to offer a balanced range of subjects including English, math, sciences, and religious education). The national curriculum has been overhauled several times since it was first introduced in 1988 (see Roberts, 2018 for a summary). The policies of the Labour government up to 2007 focused on curriculum and assessment reform, including the introduction of vocational courses, deemed equivalent to GCSEs (Lupton, Thomson, \& Obolenskaya, 2016). Beginning in 2010, under a ConservativeLiberal Democrat coalition government, there were some substantial changes to the curriculum including a reduction in the number of vocational qualifications included in the benchmarking of school results and changes to the way pupils are assessed at GCSE and A level, reducing the use of coursework and increasing the emphasis on final exams. The curriculum itself was also reformed to put more emphasis on knowledge, seen as a more traditional manner of learning, in both primary and secondary schools. It was argued that this

\footnotetext{
${ }^{9}$ Key stage 1-3 national curriculum subjects from September 2014: Maths, English, science, history, geography, art and design, physical education, music, languages (key stage 2 and key stage 3), computing, design and technology, citizenship education (key stage 3). At key stage 4 the subjects include: Maths, English, science, physical education, computing and citizenship education (Roberts, 2018).
} 
new "slimmed down" curriculum would give teachers freedom to meet the needs of their students based on their professional judgment. The rationale for this change was to give all students the opportunity to gain access to "powerful knowledge" (Young, 2010, p. 5), however it has been argued that this was undermined by the lack of thought as to improvements in pedagogy to ensure all pupils can engage with these new curricula (Whitty, 2010).

In terms of the associated outcomes of these curriculum changes for narrowing the gap, there was an improvement in GCSE attainment between 2007 and 2010, with the proportion of young people achieving $5 \mathrm{~A} * \mathrm{C}$ grades increasing from $59.9 \%$ to $75.6 \%$; however, this improvement was not found in the PISA tests over the same period, which gives rise to the possibility that the success was as a result of channeling students (especially those from less advantaged backgrounds; Henderson, Sullivan, Anders, Moulton, 2017) into vocational equivalent qualifications (Jerrim, 2012). There is also some evidence that the change to finalexam assessment has resulted in lower attainment for those at the bottom of the attainment distribution, but it may be too early to be certain of any long-term effects of these changes (Lupton et al., 2016).

\section{Academies and Free Schools}

The flagship education policy under the 2010-2015 Conservative-Liberal Democrat coalition government was perhaps the widespread role out of "academies" discussed above. However, evidence of systematic improvement as a result of widespread "academization" (Whitty \& Anders, 2017), per se, or from being part of a multi-academy trust (Bernardinelli, Rutt, Greany, \& Higham, 2018) is far from clear. There is some evidence of improvements in academic performance resulting from academization (e.g., Eyles \& Machin, 2015; Machin \& 
Vernoit, 2012). Eyles and Machin (2015) used a counterfactual design comparing academies' performance with maintained schools that went on to become academies after their data collection period and found that in academies an extra three percentage points of pupils achieved top grades ( $\left.5 \mathrm{~A}^{*}-\mathrm{C}\right)$ at GCSE (or equivalents) compared to those yet to convert. However, further work suggested these academies improved their results by "further raising the attainments of students in the top half of the ability distribution, and in particular pupils in the top $20 \%$ tail" and not by improving the results of those in the bottom tail (Machin \& Silva, 2013, p. ii).

Furthermore, as noted above there are significant differences between the academies program of the Labour government (as evaluated by most of the studies above) and that of the coalition government following 2010. Use of evidence of even modest improvements among such academies as evidence for their widespread roll-out has been criticized (Eyles, Machin, \& Silva, 2015). Work evaluating the new cohort of academies, including previously highperforming "converter" academies, is only now starting to emerge (e.g., McDool, 2016) and it remains difficult to argue that there is strong and consistent evidence that academies will help to reduce the gap between low and high SES pupils.

\section{Grammar Schools}

State-funded academically selective schools in England are known as "grammar schools" and remain a controversial area of English education policy. Despite being phased out in most parts of England between the mid-1950s and the late-1980s, they have remained a fixture in a number of areas. Since these reforms, for the most part neither major political party has been in favor of altering this state of affairs. However, soon after Theresa May became Prime Minister in July 2016, she announced a number of significant changes to the education 
policies pursued by her predecessor, including plans to lift the formal restrictions on grammar school expansion introduced by the Labour government in 1998 (but de facto in place for some time before this). May's plan was to relax the restrictions on new and expanding selective schools and to allow alteration of admissions policies in non-selective schools to become more selective in some circumstances. There are 163 grammar schools in England and in the 2017 Conservative manifesto May pledged to open 140 new free schools, many of which were expected to be grammar schools, which would open from 2020. However, the performance of the Conservative party at the June 2017 election put some of these plans on hold, although some have been revisited more recently.

The PISA-based evidence on selective schooling internationally shows that academic selection in schools is negatively associated with equality and student motivation (Organisation for Economic Co-operation and Development, 2012). There is some evidence that selective schools across Organisation for Economic Co-operation and Development countries achieve higher on average performance, even once taking account of family and demographic characteristics. However, on aggregate, an educational system's performance is not greater when a country has a higher proportion of academically selective schools. In England, the evidence is mixed; the Education Policy Institute found that in raw attainment terms $97 \%$ of grammar school pupils achieve the benchmark of five A*-C GCSEs compared to the state funded national average of 57\% (Andrews, Hutchinson, \& Johnes, 2018). However, once pupil characteristics are adjusted for there is no difference on average pupil attainment between students who study in a selective-school area compared to those who don't study in a selective school area (Andrews et al., 2018). This suggests that opening additional grammar schools will not raise attainment for all and joins others' evidence that expansion of selective schooling is likely to increase educational inequality (Burgess, 
Dickson, \& Macmillan, 2014). Andrews et al. (2018) found an individual benefit in GCSE grades for students attending a grammar school, however it is known that access to grammar schools is highly socially graded with significant sums spent on private tuition for the grammar school entry tests by those who can afford it (e.g., Andrews et al., 2018; Jerrim \& Sims, 2018).

\section{Educational Funding}

Work by Hanushek (1997) suggests that there is not a positive linear relationship between increasing school resources and student attainment. However, Hanushek acknowledges that depending on the way these resources are allocated and spent, funding can reduce the educational gap. Evidence from the UK has shown that there is a small but significant school resource effect (e.g., Dewey, Husted, \& Kenny, 2000; Holmlund, McNally, \& Viarengo, 2008). Holmlund et al. (2008) found that an increase of $£ 1,000$ per pupil is associated with an increase in the number of pupils achieving the expected level of attainment at key stage 2 (taken at age 11). The increase is by 2.2 percentage points for English; 2 percentage points for math; and 0.7 percentage points in science. More recently the evidence suggests that an increase in school funding and resource has had a small positive influence on educational attainment (Gibbons, McNally, \& Viarengo, 2017; Nicoletti \& Rabe, 2014), but this has only been found to be statistically significant at the primary school level.

A recent review by Williams and Grayson (2018) summarizes the funding context in England since 2010. They note that in real-terms funding per pupil in state schools in England has increased from the 1990s to mid-2000s but this has subsequently declined in real terms. However, the targeting of the resources involves changes: in April 2011, the government introduced the "Pupil Premium," a form of per capita funding for schools with large numbers 
of students from disadvantaged backgrounds. Initially, each school received $£ 488$ per eligible pupil with this increasing to $£ 1,320$ for primary school pupils and $£ 935$ for secondary school pupils in by $2016 / 17$. In addition, schools receive an additional $£ 1,900$ for students who were adopted, have a guardianship order, are in local-authority care, or are a looked-after child (DfE, 2017d).

The aim of this targeted funding was to give schools the autonomy to use this funding to raise the attainment of the most disadvantaged. Schools were to be held to account through England's school inspection regime and performance tables that examined the Pupil Premium category specifically. However, it's not clear the extent to which targeted spending has happened as only a small proportion of the $£ 1.25$ bn of Pupil Premium in $2012 / 13$ was earmarked to be spent on activities that are known to improve attainment levels (The Sutton Trust, 2012). Furthermore, it was not until 2013/14 that the Pupil Premium exceeded the value of grants it replaced (Lupton \& Thompson, 2015; Sibieta, Chowdry, \& Muriel, 2008), although the policy did encourage redistribution of funds to the schools with the highest concentration of disadvantaged children.

One of the many challenges faced when trying to establish the impact of the Pupil Premium policy is that factors such as peer and school composition may depress the effect of a targeted boost in resource. In 2015, the UK Parliament's Public Accounts Committee noted that the gap between disadvantaged pupils and their peers had reduced (House of Commons Committee of Public Accounts, 2015) and in 2016 the Social Mobility Commission said: "there is some evidence that the Pupil Premium has had a positive effect on the attainment gap, but is not definitive, because it cannot definitively say what would have happened to attainment had it not been introduced" (p. 81). Further doubt has been raised regarding the 
efficacy of this policy by a report published by the Education Policy Institute which showed that while there has been some progress on the closing of the attainment gap for disadvantaged pupils on average since 2007, it is closing at an unpredictable rate (Andrews, Robinson, \& Hutchinson, 2017).

\section{'What Works' and the Education Endowment Foundation}

One way in which the government has attempted to narrow the attainment gap is through its increased emphasis on funding research into 'what works' in educational attainment. This has come with a particular focus on providing evidence about changes teachers and schools can make to improve attainment among those from disadvantaged backgrounds. In 2011, the Department for Education provided the funding for the establishment of the Education Endowment Foundation (EEF) ${ }^{10}$ with the specific remit of funding robust research in this area and disseminating its findings to teachers, particularly through its 'Teaching and Learning Toolkit' and, increasingly, guidance reports focused on specific issues.

Some issues explored by the Toolkit to raise the quality of teaching and learning include the impact of mentorship and digital technologies, and making best use of teaching assistants, for example, and are assessed in terms of cost effectiveness, evidence strength and impact. Moreover, they aim to provide an accessible summary of existing international data analyses for schools and teachers to navigate the evidence-base. Since 2011 up to two-thirds of all senior leaders in schools reporting having used the Teaching and Learning Toolkit to inform decision making and over 10,000 schools, nurseries and colleges have taken part in a trial funded by the EEF. The most encouraging interventions tested through this process have accelerated student progress by three months in a year and an independent evaluation has

\footnotetext{
${ }^{10}$ The EEF is an independent charity governed by The Sutton Trust and the Impetus-Private Equity Foundation.
} 
estimated that the lifetime gains for students taking part in EEF trials amounting to three times the cost of delivering and evaluating them (EEF, 2017).

This approach has not been without controversy, with some researchers arguing that the kinds of approaches needed to improve the performance of disadvantaged pupils are not best addressed by asking 'what works?', instead advocating alternative approaches such as 'realist evaluation' that ask 'What works for whom in what circumstances and in what respects, and how?' (Pawson \& Tilley, 1997). However, we believe these should be seen as complementary, rather than competitive, and seek ways to integrate elements as proposed with approaches such as 'realist RCTs' (Bonell et al., 2012) and approaches combining improvement science with experimental approaches (Peterson, 2016). The best designed experimental evaluations already include such elements, for example by being part of an embedded mixed methods design also incorporating an implementation and process evaluation (Anders et al., 2017). Nevertheless, there is doubtless more that can be done in this respect, as highlighted by Connolly et al. (2018) in their systematic review of experimental evaluations in education.

\section{Conclusion}

This chapter has outlined key characteristics of English students and attainment inequalities associated with these, and discussed recent polices introduced to address these inequalities, including discussion of the extent to which there is evidence that these have been successful in their stated aims. Because it is always difficult to isolate the effects of policy changes that occur on a national basis, our conclusions on this last point are particularly tentative. 
In international terms, England is a country with low levels of disadvantage. However, there are sizeable differences in educational attainment by SES and we see little evidence of substantial or sustained narrowing in these attainment gaps in recent years. There are also concerns that well-intentioned policies will fail to narrow the attainment gap due to the ways they have been implemented.

For example, while the introduction of academies may have helped to improve the performance of some schools, the evidence on their efficacy is mixed and suggests performance improvements have come from those at the top of the attainment distribution, not the bottom. Changes to school funding to increase resources for those with more disadvantaged pupils through the Pupil Premium have not included sufficient accountability to ensure they are used to improve the attainment of disadvantaged pupils. Likewise, the introduction of curricular reforms aimed at widening access to "powerful knowledge" may be hampered by lack of consideration of the need to tailor this curriculum for pupils from all backgrounds. Meanwhile, there are also signs that some policy changes are likely to be detrimental for those from disadvantaged backgrounds, most notably the mooted expansion of selective schooling, which is highly likely to widen the gap between the top and the bottom of the attainment distribution.

As such, it is far from clear that many of England's recent reforms hold lessons for other countries wishing to reduce their attainment gaps. However, this is not the case across the board. Notable exceptions include the increased investment in widening access to high-quality pre-school education and increased focus on delivering and disseminating robust evidence on school- and classroom-level interventions that will narrow the attainment gap. 


\section{References}

Anders, J. (2012). The link between household income, university applications and university attendance. Fiscal Studies, 33(2), 185-210. doi:10.1111/j.1475-5890.2012.00158.x

Anders, J. (2017). The influence of socioeconomic status on changes in young people's expectations of applying to university. Oxford Review of Education, 43(4), 381-401. doi:10.1080/03054985.2017.1329722

Anders, J., Brown, C., Ehren, M., Greany, T., Nelson, R., Heal, J., Groot, A., Sanders, M., \& Allen, R. (2017). Evaluation of Complex Whole-School Interventions: Methodological and Practical Considerations. Report to the Education Endowment Foundation.

Anders, J., Henderson, M., Moulton, V., \& Sullivan, A. (2018a). Incentivising specific combinations of subjects-Does it make any difference to university access? National Institute Economic Review, 243(1), R37-R52. doi:10.1177/002795011824300113

Anders, J., Henderson, M., Moulton, V., \& Sullivan, A. (2018b). The role of schools in explaining individuals' subject choices at age 14. Oxford Review of Education, 44(1), 75-93. doi:10.1080/03054985.2018.1409973

Anders, J., \& Jerrim, J. (2017). The socio-economic gradient in educational attainment and labour market outcomes: a cross-national comparison. In I. Schoon \& R. K. Silbereisen (Eds.), Pathways to adulthood: Social inequalities, structure and agency and social change (pp. 25-50). London, UK: UCL IOE Press.

Andrews, J., Hutchinson, J., \& Johnes, R., (2018). Grammar schools and social mobility. London, UK: Education Policy Institute. Retrieved from https://epi.org.uk/wpcontent/uploads/2018/01/Grammar-schools-and-social-mobility_.pdf

Andrews, J., Robinson, D., \& Hutchinson, J. (2017). Closing the gap? Trends in educational attainment and disadvantage. London, UK: Education Policy Institute. Retrieved from 
https://epi.org.uk/publications-and-research/closing-gap-trends-educational-attainmentdisadvantage/

Bernardinelli, D., Rutt, S., Greany, T., \& Higham, R. (2018). Multi-academy trusts: Do they make a difference to pupil outcomes? London, UK: UCL IOE Press.

Boliver, V. (2013). How fair is access to more prestigious UK universities? The British Journal of Sociology, 64(2), 344-364. doi:10.1111/1468-4446.12021

Bonell, C., Fletcher, A., Morton, M., Lorenc, T. and Moore, L. (2012). 'Realist randomized controlled trials: a new approach to evaluating complex public health interventions', Social Science \& Medicine, 75 (12), pp. 2,299-2,306.

Burgess, S., Dickson, M., \& Macmillan, L. (2014). Selective schooling systems increase inequality (DoQSS Working Paper 14-09). London, UK: UCL Institute of Education. Retrieved from https://ideas.repec.org/s/qss/dqsswp.html

Chowdry, H., Crawford, C., Dearden, L., Goodman, A., \& Vignoles, A. (2013). Widening participation in higher education: Analysis using linked administrative data. Statistics in Society, Series A, 176(2), 431-457. doi:10.1111/j.1467-985X.2012.01043.x

Connolly, P., Keenan, C. \& Urbanska, K. (2018). The trials of evidence-based practice in education: a systematic review of randomised controlled trials in education research 1980-2016, Educational Research, 60:3, 276-291, DOI:

$10.1080 / 00131881.2018 .1493353$

Crawford, C., Macmillan, L, \& Vignoles, A. (2017). When and why do initially highachieving poor children fall behind? Oxford Review of Education, 43(1), 88-108. doi:10.1080/03054985.2016.1240672

Department for Education. (2010). Provision for children under five years of age in England-January 2010. London, UK: Author. Retrieved from 
https://data.gov.uk/dataset/d3954344-470b-4e5d-8bf4-6b4f77c0f6c4/provision-forchildren-under-five-years-of-age-in-england

Department for Education. (2014). Measuring disadvantaged pupils' attainment gaps over time (Statistical Working Paper SFR 40/2014). London, UK: Author. Retrieved from https://www.gov.uk/government/statistics/measuring-disadvantaged-pupils-attainmentgaps-over-time

Department for Education. (2015). Education provision: Children under 5 years of age, January 2015. London, UK: Author. Retrieved from https://www.gov.uk/government/statistics/provision-for-children-under-5-years-of-agejanuary-2015

Department for Education. (2017a). Destinations of key stage 4 and key stage 5 students, England, 2015/16. London, UK: Author. Retrieved from https://assets.publishing.service.gov.uk/government/uploads/system/uploads/attachment _data/file/651012/SFR56_2017_Main_Text.pdf

Department for Education. (2017b). National curriculum assessments at key stage 2 in England, 2017 (revised). London, UK: Author. Retrieved from https://www.gov.uk/government/uploads/system/uploads/attachment_data/file/667372/S FR69_2017_text.pdf

Department for Education. (2017c). Participation rates in higher education: Academic years 2006/2007-2015/2016 (provisional). London, UK: Author. Retrieved from https://assets.publishing.service.gov.uk/government/uploads/system/uploads/attachment _data/file/648165/HEIPR_PUBLICATION_2015-16.pdf

Department for Education. (2018a). Pupil premium: Funding and accountability for schools. London, UK: Author. Retrieved from https://www.gov.uk/guidance/pupil-premium- 
information-for-schools-and-alternative-provision-settings\#funding-for-financial-year2016-to-2017

Department for Education. (2017d). Schools, pupils and their characteristics: January 2017 (SFR 28.2017). London, UK: Author.

https://www.gov.uk/government/uploads/system/uploads/attachment_data/file/650547/S FR28_2017_Main_Text.pdf

Department for Education. (2018b). Revised 2018 GCSE and equivalent results in England, 2016 to 2017 (SFR01/2017). London, UK: Author. Retrieved from https://assets.publishing.service.gov.uk/government/uploads/system/uploads/attachment _data/file/676596/SFR01_2018.pdf

Department for Work and Pensions. (2017a). Households below average income: 1994/95 to 2015/16. London, UK: Author. Retrieved from https:/www.gov.uk/government/statistics/households-below-average-income-199495to-201516

Department for Work and Pensions. (2017b). Households below average income: 1994/95 to 2016/17. London, UK: Author. Retrieved from https://www.gov.uk/government/uploads/system/uploads/attachment_data/file/691899/d irectory-of-tables-hbai-2016-17.ods

Dewey, J., Husted, T. A., \& Kenny, L. W. (2000). The ineffectiveness of school inputs: A product of misspecification? Economics of Education Review, 19(1), 27-45. doi:10.1016/S0272-7757(99)00015-1

Education Endowment Foundation (2017). The attainment gap//2017. Retrieved from https://educationendowmentfoundation.org.uk/public/files/Annual_Reports/EEF_Attain ment_Gap_Report_2018_-_print.pdf 
Eyles, A., \& Machin, S. (2015). The introduction of academy schools to England's education. London, UK: Centre for Economic Performance, London School of Economics.

Eyles, A., Machin, S., \& Silva, O. (2015). Academies 2: The new batch (CEP Discussion Paper No. 1370). London, UK: Centre for Economic Performance, London School of Economics. Retrieved from http://cep.lse.ac.uk/pubs/download/dp1370.pdf

Gibbons, S., McNally, S., \& Viarengo, M. (2017). Does additional spending help urban schools? An evaluation using boundary discontinuities. Journal of the European Economic Association, 1-51. doi:10.1093/jeea/jvx038

Greany, T., \& Higham, R. (2018). Hierarchy, markets and networks: Analysing the "selfimproving school-led system" agenda in Britain and the implications for schools. London, UK: UCL IOE Press.

Hanushek, E. A. (1997). Assessing the effects of school resources on student performance: An update. Educational Evaluation and Policy Analysis, 19(2), 141-164. doi:10.3102/01623737019002141

Henderson, M., Sullivan, A., Anders, J., \& Moulton, V. (2017). Social class, gender and ethnic differences in subjects taken at age 14. The Curriculum Journal. doi:10.1080/09585176.2017.1406810

Holmlund, H., McNally, S., \& Viarengo, M. (2008). Impact of school resources on attainment at key stage 2 (DCSF Research Report No. RR043). London, UK: Department for Children, Schools and Families.

House of Commons Committee of Public Accounts. (2015). Funding for disadvantaged pupils: Third Report of Session 2015-16. London, UK: The Stationery Office Limited. Retrieved from https://publications.parliament.uk/pa/cm201516/cmselect/cmpubacc/327/327.pdf 
Ilie, S., Sutherland, A., \& Vignoles, A. (2017). Revisiting free school meal eligibility as a proxy for pupil socio-economic deprivation. British Educational Research Journal, 43(2), 253-274. doi:10.1002/berj.3260

Jerrim, J. (2012). The reliability of trends over time in international education test scores: Is the performance of England's secondary school pupils really in relative decline? Journal of Social Policy, 42(2), 259-279. doi:10.1017/S0047279412000827

Jerrim, J., \& Micklewright, J. (2014). Socio-economic gradients in children's cognitive skills: Are cross-country comparisons robust to who reports family background? European Sociological Review, 30(6), 766-781. doi:10.1093/esr/jcu072

Jerrim, J., \& Sims, S. (2018, March). Why do so few low and middle-income children attend a grammar school? New evidence from the Millennium Cohort Study. Retrieved from https://johnjerrim.files.wordpress.com/2018/03/working_paper_nuffield_version_clean. pdf

Lupton, R., \& Thomson, S. (2015). Socio-economic inequalities in English schooling under the Coalition Government 2010-2015. London Review of Education, 13(2), 4-20.

Lupton, R., Thomson, S., \& Obolenskaya, P. (2016). Schools. In R. Lupton, T. Burchardt, J. Hills, K. Steward, \& P. Vizard (Eds.), Social policy in a cold climate: Policies and their consequences since the crisis (pp. 59-79). Bristol, UK: Policy Press.

Machin, S., \& Silva, O. (2013, March). School structure, school autonomy and the tail (CEP Special Paper No. 29). Retrieved from http://cep.lse.ac.uk/pubs/download/special/cepsp29.pdf

Machin, S., \& Vernoit, J. (2012). Changing school autonomy: Academy schools and their introduction to England's education (CEE Discussion Paper No. 123). Retrieved from http://cee.lse.ac.uk/ceedps/ceedp123.pdf 
McDool, E. (2016). The effect of primary converter academies on pupil performance (Sheffield Economic Research Paper Series No. 2016013). Retrieved from https://www.sheffield.ac.uk/polopoly_fs/1.670238!/file/paper_2016013.pdf

McGuinness, F. (2018). Poverty in the UK: Statistics (House of Commons Library Briefing Paper No. 7096). Retrieved from http://researchbriefings.files.parliament.uk/documents/SN07096/SN07096.pdf

Moulton, V. G., Sullivan, A., Henderson, M., \& Anders, J. (2018). Does what you study at age 14-16 matter for educational transitions post-16? Oxford Review of Education, 44(1), 94-117. doi:10.1080/03054985.2018.1409975

Nicoletti, C., \& Rabe, B. (2014). Spending it wisely: How can schools use their resources to help poorer pupils? Colchester, UK: Institute for Social and Economic Research. Retrieved from https://www.iser.essex.ac.uk/files/news/2014/spending-it-wisely.pdf

Office of National Statistics. (2017). Statistical bulletin: Families and households: 2017. Retrieved from https://www.ons.gov.uk/peoplepopulationandcommunity/birthsdeathsandmarriages/fami lies/bulletins/familiesandhouseholds/2017

Organisation for Economic Co-operation and Development. (2012). PISA 2012 results: What makes schools successful? Resources, policies and practices (Vol. IV). Paris, France: OECD Publishing. Retrieved from https://www.oecd.org/pisa/keyfindings/pisa-2012results-volume-IV.pdf

Pawson, R. and Tilley, N. (1997). Realistic Evaluation, Sage.

Peterson, A. (2016). Getting 'What Works' working: building blocks for the integration of experimental and improvement science, International Journal of Research \& Method in Education, 39:3, 299-313, DOI: 10.1080/1743727X.2016.1170114 
Roberts, N. (2018). The school curriculum in England (House of Commons Library Briefing Paper No. 06798). Retrieved from http://researchbriefings.files.parliament.uk/documents/SN06798/SN06798.pdf

Schneider, S. L. (2008). The application of the ISCED-97 to the UK's educational qualifications. In S. L. Schneider (Ed.), The International Standard Classification of Education (ISCED-97): An evaluation of content and criterion validity for 15 European countries (pp. 281-300). Mannheim, Germany: MZES. Retrieved from https://www.mzes.unimannheim.de/publications/misc/isced_97/schn08e_the_application_of_the_isced97_to_the_uks_educat.pdf

Sibieta, L., Chowdry, H., \& Muriel, A. (2008). Level playing field? The implications of school funding (CfBT Education Trust Research Paper). Retrieved from https://www.ifs.org.uk/docs/level_playing.pdf

Social Mobility Commission. (2016). State of the nation 2016: Social mobility in Great Britain. Retrieved from https://assets.publishing.service.gov.uk/government/uploads/system/uploads/attachment _data/file/569410/Social_Mobility_Commission_2016_REPORT_WEB_1_.pdf

Stewart, K., \& Obolenskaya, P. (2016). Young children. In R. Lupton, T. Burchardt, J. Hills, K. Stewart, \& P. Vizard (Eds.), Social policy in a cold climate: Policies and their consequences since the crisis (pp. 35-58). Bristol, UK: Policy Press.

Strand, S. (2016). Do some schools narrow the gap? Differential school effectiveness revisited. Review of Education, 4(2), 107-144. doi:10.1002/rev3.3054

The Sutton Trust. (2012). NFER Teacher Voice Omnibus 2012: The use of the Pupil Premium. Slough, UK: National Foundation for Educational Research. Retrieved from https://www.nfer.ac.uk/publications/91062/91062.pdf 
Wakeling, P., \& Laurison, D. (2017). Are postgraduate qualifications the "new frontier of social mobility"? The British Journal of Sociology, 68(3), 533-555. doi:10.1111/14684446.12277

Whitty, G. (2010, July). Who you know, what you know or knowing the ropes? New evidence in the widening participation debate. Paper presented at the Festival of Education, Wellington College, Crowthorne, UK.

Whitty, G., \& Anders, J. (2017). "Closing the achievement gap" in English cities and towns in the twenty-first century. In W. Pink \& G. Noblit (Eds.), Second international handbook of urban education (pp. 1079-1101). Dordrecht, The Netherlands: Springer.

Williams, M., \& Grayson, H. (2018). School funding in England since 2010-What the key evidence tells us. Slough, UK: NFER.

Young, M. (2010). Alternative educational futures for a knowledge society. European Educational Research Journal, 9(1), 1-12. doi:10.2304/eerj.2010.9.1.1 